\title{
PENGGUNAAN ECENG GONDOK (Eichhornia crassipes)TERFERMENTASI DALAM RANSUM ITIK TERHADAP KECERNAAN BAHAN KERING DAN BAHAN ORGANIK
}

\author{
Ronald Rompas, B Tulung, J. S. Mandey*, M. Regar \\ Fakultas Peternakan Universitas Sam Ratulangi, 95115
}

\begin{abstract}
ABSTRAK
Penelitian bertujuan untuk mengetahui sejauhmana penggunaan eceng gondok

(eichhornia crassipes)terfermentasi (EGT) dalam ransum itik terhadap kecernaan bahan kering dan bahan organik.Penelitian dilaksanakan selama 3(tiga) minggudengan menggunakan 20 ekor itik Mojosari-Alabio (MA), umur 8 minggu. Penelitian dilakukan dengan menggunakan rancangan acak lengkap yang terdiri dari5 perlakuan dan 4 ulangan.Perlakuan terdiri atas R0 $(0 \%$ EGT), R1(10\% EGT), R2 (20\% EGT), R3 (30\% EGT), R4 (40\% EGT). Hasil penelitian menunjukkan bahwa perlakuan memberikan pengaruh yang berbeda sangat nyata $(\mathrm{P}<0,01)$ terhadap kecernaan bahan kering dan kecernaan bahan organik. Hasil uji lanjut dengan uji beda nyata jujur (BNJ) menunjukkan bahwa tidak terdapat perbedaan yang nyata pada kecernaan bahan kering antara perlakuan R0 (70,86\%), R1 (71,08\%), R2 (70,47\%), dan R4 (69,47\%). Perlakuan R3 nyata lebih tinggi dibandingkan perlakuan $\mathrm{R} 4$, namun tidak berbeda nyata dengan perlakuan R0 dan R1. Hasil uji BNJ terhadapkecernaan bahan organik menunjukkan bahwa perlakuan R3 (76.27) tidak berbeda nyata dengan perlakuan R0 (75,30\%), R1 (75,43\%), dan R2 $(75,17 \%$, namun nyata lebih tinggi dibandingkan perlakuan R4 (74,13\%). Sementara untuk perlakuan R0, R1, R2, dan R4 tidak terdapat perbedaan.Dapat disimpulkan bahwa eceng gondok terfermentasi dapat digunakansampai level $30 \%$ dalam pakan itik menggantikan dedak halus.
\end{abstract}

*Korespondensi (corresponding Author)

Email: jetsm_fapet@yahoo.co.id
Kata kunci :Eceng gondok terfermentasi, kecernaan, bahan kering, bahan organic

ABSTRACT
UTILIZATION OF FERMENTED
WATER HYACINTH (Eichhornia
crassipes) IN DUCK DIETS ON DRY
MATTER AND ORGANIC MATTER
DIGESTIBILITY.The study aimed to
determine the use of fermented water hyacinth (Eichhornia crassipes) (FWH) in duck dietson dry matter and organic matter digestibility. This study was carried out for three weeks using 20 crossbred ducks of Mojosari and Alabio (MA), 8 weeks of age. This study was conducted using a completely randomized design with 5 treatments and 4 replications. The treatments were R0 (0\% FWH), R1 (10\% FWH), R2 (20\% FWH), R3 (30\% FWH), R4 (40\% FWH). Results showed that treatments was highly significant $(\mathrm{P}<0.01)$ affectedto dry matter and organic matter digestibility. Honestly significant difference test (HSD) on dry matter digestibility showed that there were no significant between treatment R0 (70.85\%), R1 (71.08\%), R2 (70,47\%) and R4 (69.47\%). The R3 diet was significantly higher than R4, but was not significantlydifferentbetween R0 and R1. The HSDtest on organic matter digestibility showed that there was no significant difference between R3 (76 27) and R0 (75.30\%), R1 (75.43\%) and R2 (775,17\%), but R3 was significantly higher than R4 (74.13\%). There were no significant differencebetween R0, R1, R2, and $\mathrm{R} 4$ diets. It can be concluded that fermented water hyacinth reach can be used till $30 \%$ in duck diet substituted to rice bran.

Keywords:Fermented water hyacinth, Digestibility,Dry matter, Organic matter 


\section{PENDAHULUAN}

Ternak itik adalah salah satu komoditi bidang peternakan yang berperan sebagai penghasil daging dan telur.Pengembangan usaha peternakan itik terkendalapenyediaan pakan berkualitas,terlebih dalam menjaga stabilitas usaha peternakan.Pakan berkualitas sangat dibutuhkan guna menunjang produktivitas ternak, khususnya untuk menunjang ternak yang sedang berproduksi.

Penyediaan bahan pakan berkualitas selama ini bersumber dari pemanfaatan bahan konvensional, namun dalam penggunaannya terkendala beberapa faktor, yaituketersediaan yang fluktuatif, persaingan kebutuhan dengan ternak monogastrik lainnya serta harga yang tidak stabil. Seperti halnya dedak halus, yang merupakan salah satu bahan yang sering digunakan sebagai bahan pakan penyusun ransum,namun memiliki beberapa kelemahan seperti ketersediaanya yang fluktuatif ditambah lagi penggunaannya kini bersaing dengan ternak monogastrik lainnya, menjadifaktor penyebab terjadinya kelangkaan bahan serta ketidak stabilan harga bahan. Untuk menekan biaya produksi serta mengatasi terjadinya kelangkaan bahan pakan perlu untuk melakukan pencarian dan pemanfaatan bahan alternatif dari bahanin konvensional.

Eceng gondok merupakan salah satu bahan inkonvensional yang dapat dimanfaatkan sebagai pakan alternatif.Tanaman ini dianggap sebagai tanaman yang mengganggu perairan.Menurut Bates dan Hentges (1976) produksi eceng gondok mencapai 168ton/Ha/tahun.Pemanfaatan eceng gondok sebagai pakan ternak terbatas karena kandungan nutriennya yang rendah.Oleh karena itu, melalui penerapan teknologi fermentasi, pemanfaatan eceng gondok pada ternak itikakanlebih baik karena terjadi perbaikankandungan nutrien secara kualitatif. Komposisi kimia eceng gondok terfermentasi berdasarkan analisis laboratorium Fapet, Universitas Brawijaya (2013), yaitu PK 15,9\%; SK 14,63\%; Abu 9,70\%; GE $3202 \mathrm{Kkal} / \mathrm{kg}$.

Hasil penelitian penggunaan eceng gondok fermentasi seperti dilaporkan Tanjung (2001)bahwa eceng gondok terfermentasi dapat digunakan dalam ransum broiler sampai level 20\%.Mangisah, dkk. (2010) melaporkan bahwa penggunaan daun eceng gondok fermentasi Aspergillus niger dalam ransum itik tegal umur 8 minggu meningkatkan kecernaan protein kasar, energy metabolis sejati (TME), dan retensi nitrogen. 
MATERI DAN METODE

\section{PENELITIAN}

Penelitan ini dilaksanakan selama tiga minggu terhadap ternak itik.Itik yang digunakan adalah itik jantan hasil persilangan itik Mojosari dan itik Alabio ( itikMA), yang ditempatkan dalam kandang battery sebanyak 20 unit dan setiap unit diisi 1 ekor itik. Kandang dilengkapi dengan tempat makan dan minumyang ditempatkan dalam ruangan berventilasi dengan pencahayaan yang cukup.Bahan pakan yang digunakan sebagai penyusun ransum dan komposisi nutriennya sertasusunan ransum perlakuan sertakomponen zat-zat makanan selengkapnya dapat dilihat pada Tabel 1 dan Tabel 2.

Tabel 1. Komposisi Nutrien dan Energi Metabolis Bahan Pakan Penyusun Ransum

\begin{tabular}{|c|c|c|c|c|c|c|}
\hline \multirow[b]{2}{*}{ Bahan Pakan } & \multicolumn{5}{|c|}{ Komposisi Zat-zat Makanan (\%) } & \multirow[b]{2}{*}{$\begin{array}{c}\mathrm{GE} \\
(\mathrm{Kkal} / \mathrm{kg})\end{array}$} \\
\hline & $\begin{array}{c}\text { Protein } \\
\text { Kasar }\end{array}$ & $\begin{array}{l}\text { Serat } \\
\text { Kasar }\end{array}$ & Lemak & $\mathrm{Ca}$ & $\mathrm{P}$ & \\
\hline Jagung Kuning $\left.{ }^{*}\right)$ & 9,42 & 2,15 & 5,17 & 0,22 & 0,60 & 3977,5 \\
\hline Bungkil Kelapa*) & 24,7 & 15,02 & 9,36 & 0,68 & 0,78 & 4327,5 \\
\hline tepung kedelai ${ }^{*}$ & 49,0 & 2,27 & 8,26 & 0,11 & 0,47 & 4887,5 \\
\hline Tepung Ikan*) & 55,0 & 0,17 & 12,10 & 0,32 & 0,58 & 4335 \\
\hline Dedak Halus $\left.{ }^{* *}\right)$ & 9,90 & 12,83 & 6,06 & 5,10 & 2,80 & 3100 \\
\hline $\left.\mathrm{EGF}^{* *}\right)$ & 15,9 & 14,63 & - & 2,18 & 1,43 & 3202 \\
\hline top $\left.\operatorname{mix}^{*}\right)$ & - & - & - & 5,38 & 1,44 & - \\
\hline
\end{tabular}

${ }^{*}$ Hasil Analisis Laboratorium Fakultas Peternakan Universitas Padjajaran (2013)

${ }^{* *}$ EGF = Eceng gondok fermentasi; Hasil Analisis Laboratorium Fakultas Peternakan Universitas Brawijaya (2013)

Tabel 2. Susunan Bahan Pakan dan Komposisi Nutrien Ransum Perlakuan

\begin{tabular}{|c|c|c|c|c|c|}
\hline \multirow{3}{*}{ Bahan Pakan } & \multicolumn{5}{|c|}{ Perlakuan } \\
\hline & RO & R1 & $\mathrm{R} 2$ & R3 & R4 \\
\hline & \multicolumn{5}{|c|}{ Proporsi (\%) } \\
\hline Jagung Kuning & 40 & 40 & 40 & 40 & 40 \\
\hline Bungkil Kelapa & 4 & 4 & 4 & 4 & 4 \\
\hline Tepung Kedele & 6 & 6 & 6 & 6 & 6 \\
\hline Tepung Ikan & 9 & 9 & 9 & 9 & 9 \\
\hline Dedak Halus & 40 & 30 & 20 & 10 & - \\
\hline EGF & - & 10 & 20 & 30 & 40 \\
\hline top mix & 1 & 1 & 1 & 1 & 1 \\
\hline Total & 100 & 100 & 100 & 100 & 100 \\
\hline \multicolumn{6}{|c|}{ Komposisi Nutrien, , Bahan kering, Abu, dan Gross Energy } \\
\hline Bahan Kering $(\%)^{*}$ & 89.69 & 89.70 & 89.86 & 89.65 & 89.75 \\
\hline Protein $(\%)^{*}$ & 17.68 & 18.23 & 18.24 & 18.47 & 18.48 \\
\hline Lemak $(\%)^{*}$ & 6.40 & 6.39 & 5.81 & 5.80 & 5.80 \\
\hline Serat Kasar $(\%)^{*}$ & 13.93 & 14.19 & 14.61 & 14.87 & 15.30 \\
\hline $\mathrm{Ca}(\%)^{* *}$ & 0,89 & 1,04 & 1,19 & 1,34 & 1,49 \\
\hline $\mathrm{P}(\%)^{* *}$ & 0,86 & 0,91 & 0,98 & 1,04 & 1,11 \\
\hline $\operatorname{Abu}(\%)^{*}$ & 11.39 & 11.50 & 11.62 & 11.80 & 12.13 \\
\hline $\mathrm{GE}(\mathrm{Kkal} / \mathrm{kg})^{*}$ & 3860.20 & 3919.83 & 4006.95 & 4061.07 & 4147.61 \\
\hline
\end{tabular}


Perlengkapan yang digunakan adalah timbangan, wadah penampung bahan pakan penyusun ransum, wadah untuk mencampur

ransum

perlakuan,kantongplastik

penampung

ransum per perlakuan, penampung ekskreta,dan alat tulis menulis.Penelitian ini dilakukan dengan menggunakan metode eksperimen dengan Rancangan Acak Lengkap sesuai petunjuk Steel dan Torrie (1991), terdiri dari 5 perlakuan dan 4 ulangan.Ransum perlakuan yang diberikan diformulasi sebagai berikut: R0 $=100 \%$ dedak halus (40\% dalam ransum) $+0 \%$ eceng gondok fermentasi $(0 \%$ dalam ransum); $\mathrm{R} 1=75 \%$ dedak halus $(30 \%$ dalam ransum) $+25 \%$ eceng gondok fermentasi (10\% dalam ransum); $\mathrm{R} 2=$ $50 \%$ dedak halus (20\% dalam ransum) + $50 \%$ eceng gondok fermentasi (20\% dalam ransum); R3 = 25\% dedak halus $(10 \%$ dalam ransum) $+75 \%$ eceng gondok fermentasi (30\% dalam ransum); $\mathrm{R} 4=0 \%$ dedak halus $(0 \%$ dalam ransum $)+100 \%$ eceng gondok fermentasi $(40 \%$ dalam ransum). Pengaruh perlakuan ransum percobaan dianalisis keragamannya dan selanjutnya untuk mengetahui perbandingan antar perlakuan, analisis dilanjutkan dengan Uji Beda Nyata Jujur (BNJ) sesuai petunjuk Steel dan Torrie (1991).

\section{Prosedur Penelitian}

Penelitian ini dibagi dalam dua tahap, yaitu tahap pertama, yaitu adaptasi ransum perlakuan dan tahap kedua, yaitu pengambilan data ekskreta. Tahap pertama, yaitu tahap adaptasi dilakukan selama 10 hari dimana pakan perlakuan diberikan secara bertahap sampai ransum perlakuan menggantikan ransum yang sebelumnya. Tujuannya ialah untuk menghilangkan pengaruh ransum sebelumnya pada ternak.Setelah ransum perlakuan menggantikan ransum sebelumnya, pemberiannya dilakukan secara adlibitum sampai konsumsi ternak kembali normal.

Tahap kedua ini dilakukan pengumpulan data ekskreta yang dilakukan sejak pukul 07.00 pagi sampai pukul 07.00 pagi keesokan harinya. Pengambilan data sampel ekskreta dilakukan dengan menggunakan metode koleksi total dengan cara menampung sampel ekskreta dalam wadah penampungan dan dilakukan penimbangan setiap kali defikasi. Sampel ekskreta segar dibersihkan, selanjutnya pengeringan matahari sampai sampel mencapai berat kering setelah itu sampel ditimbang dan dicampur secara komposit untuk masing-masing perlakuan. Ekskreta selanjutnya dianalisis di laboratorium untuk mendapatkan data kandungan bahan kering dan abu.

\section{Parameter}

Untuk melihat sejauh mana pengaruh penggunaan eceng gondok terfermentasi dalam ransum pada ternak itik diukur dua parameter, yaitu kecernaan bahan kering dan kecernaan bahan organik. 


\section{HASIL DAN PEMBAHASAN}

Table 3.Rataan persentase kecernaan bahan kering dan bahan organik tiap perlakuan

\begin{tabular}{lccccc}
\hline \multirow{2}{*}{ Variabel } & \multicolumn{5}{c}{ Perlakuan } \\
\cline { 2 - 6 } & $\mathrm{R} 0$ & $\mathrm{R} 1$ & $\mathrm{R} 2$ & $\mathrm{R} 3$ & $\mathrm{R} 4$ \\
\hline $\begin{array}{l}\text { Kecernaan bahan } \\
\text { kering (\%) }\end{array}$ & $70.856^{\mathrm{ab}}$ & $71.078^{\mathrm{ab}}$ & $70,470^{\mathrm{ab}}$ & $71.596^{\mathrm{b}}$ & $69.475^{\mathrm{a}}$ \\
$\begin{array}{l}\text { Kecernaan bahan } \\
\text { organik }(\%)\end{array}$ & $75.302^{\mathrm{ab}}$ & $75.430^{\mathrm{ab}}$ & $75,167^{\mathrm{ab}}$ & $76.266^{\mathrm{b}}$ & $74.131^{\mathrm{a}}$ \\
\hline $\begin{array}{l}\text { Keterangan : Nilai pada baris yang sama dengan superskrip yang berbeda menunjukkan perbedaan } \\
\text { yang nyata }(\mathrm{P}<0.05) .\end{array}$
\end{tabular}

\section{Kecernaan Bahan Kering}

Rataan kecernaan bahan kering dalam penelitian ini berkisar antara $69.435 \%-71.596 \%$.Berdasarkan hasil analisis keragaman, penggunaan eceng gondokterfermentasi dalam ransum itik memberikan pengaruh berbeda sangat nyata $(\mathrm{P}<0.01)$ terhadap nilai kecernaan bahan kering (lampiran 1). Hasil uji BNJ menunjukkan, bahwaantara perlakuan R0, $\mathrm{R} 1, \mathrm{R} 2$, dan R4 tidak terdapat perbedaan yang nyata $(\mathrm{P}>0.05)$, sama halnya dengan perlakuan R0, R1, dan R3 tidak berbeda nyata. Perlakuan R3 nyata lebih tinggi dibandingkan perlakuan R4.Nilai kecernaan bahan kering dalam penelitian ini menunjukkan bahwa penggunaan eceng gondok terfermentasi pada level $40 \%$ dalam ransum menghasilkan angka kecernaan yang tidak berbeda dengan ransum kontrol.

Hasil penelitian Cahyadi, dkk. (2014) menunjukkan bahwa rataan kecernaan bahan kering, ransum itik yang menggunakan eceng gondok fermentasi berkisar antara 79,36-80,38\% dengan level pemberian 5-10\% pada itik yang dipelihara 2-10 minggu. Rataan kecernaan bahan kering pada penelitian ini lebih rendah dibandingkan kecernaan bahan kering pada penelitian Cahyadi, dkk. (2014).Hal ini karena pengaruh level pemberian eceng gondok fermentasi pada penelitian tersebut lebih rendah, dibandingkan dengan penelitian ini sehingga kandungan serat kasar ransumnya lebih rendah. Semakin tinggi level penggunaan eceng gondok dalam ransum maka semakin tinggi pula kandungan serat kasar ransum. Kandungan serat kasar yang tinggi dalam ransum akan mempercepat gerak laju makanan dalam saluran pencernaan yang berpengaruh terhadap kecernaan zat-zat makanan. Kecernaan bahan kering dipengaruhi oleh kecernaan dari komponen bahan kering itu sendiri seperti protein, karbohidrat (BETN dan serat kasar), lemak, dan abu. 
Kecernaan bahan kering berdasarkan uji lanjut BNJ menunjukkan perlakuan R3 (penggantian $30 \%$ EGF atau $75 \%$ dalam ransum) nyata lebih tinggi dibandingkan dengan perlakuan R2 dan R4. Tingginya kecernaan bahan kering pada perlakuan R3 dibanding perlakuan $\mathrm{R} 2$ dan $\mathrm{R} 4$ diduga disebabkan lebih tingginya konsumsi ransum pada perlakuan tersebut. Selain itu, disebabkan oleh perubahan kualitas nutrisi pakan karena proses fermentasi. Banyaknya kandungan bahan kering yang dicerna berhubungan dengan banyaknya kandungan nutrien yang terserap. Hal ini menunjukkan bahwa penggunaan eceng gondok pada level 30\% dalam ransum tidak berpengaruh negatif terhadap kecernaan bahan kering

\section{Kecernaan Bahan Organik}

Rataan nilai kecernaan bahan organik ransum yang menggunakan eceng gondok fermentasi (Eichhornia crassipes) dalam penelitian ini berkisar antara 74,131\%-76,266\%. Berdasarkan hasil analisis keragaman, penggunaan eceng gondok fermentasi dalam ransum itik memberikan pengaruh berbeda nyata $(\mathrm{P}<0.05)$ terhadap nilai kecernaan bahan organik. Hasil uji BNJ menunjukkan perlakuan R3 berbeda tidak nyata dengan perlakuan R0, R1, dan R2, namun nyata lebih tinggi dibandingkan R4, sedangkan antara perlakuan R0, R1, R2, dan R4 tidak berbeda nyata.
Penggunaan eceng gondok fermentasi sampai level $30 \%$ dalam ransum berpengaruh positif terhadap kecernaan bahan organik ransum. Hal ini terjadi karena pada proses fermentasi eceng gondok terjadi peningkatan nutrient eceng gondok secara kualitatif seperti peningkatan protein serta penurunan serat kasar. Perubahan nilai dan kualitas nutrien ini menyebabkan lebih meningkatnya nilai guna eceng gondok dalam alat penernaan ternak itik.Hal ini didukung oleh pendapat dari Tillman,et al. (1989) yang mengemukakan bahwa faktor yang mempengaruhi kecernaan bahan organik adalah kandungan zat nutrisi dalam ransum.

Kisaran kecernaan bahan organik dalam penelitian ini lebih tinggi dibandingkan hasil penelitian kecernaan bahan organik oleh Mangisah, dkk. (2009) yang berkisar antara 52,81\%-72,41\%. Kecernaan bahan organik dipengaruhi oleh kecernaan dari komponen bahan organik, yaitu protein, karbohidrat (BETN dan serat kasar) dan lemak (Mangisah,dkk., 2006). Guna mencapai daya cerna bahan organik yang optimal, nilai nutrien dari komponen bahan organik harus disesuaikan dengan kebutuhan ternak itik itu sendiri.

\section{KESIMPULAN}

Berdasarkan nilai kecernaan bahan kering dan bahan organik, dapat disimpulkan bahwa eceng gondok 
(Eichhornia crassipes)terfermentasi dapat digunakan dalam pakan itik sampai level $30 \%$ menggantikan dedak halus.

\section{DAFTAR PUSTAKA}

Bates, R.P.and J.F. Hentges Jr. 1976. Aquatic weeds - Eradicate or Cultivate? Economic Botany, Vol. 30(1):39-50.

Cahyadi, R., U.Atmomarsono, E. Suprijatna. 2014. Kecernaan ransum, kadarSerum aminotransferase dan Aktivitas alkalin Fosfatase Itik Local yang diberi pakan mengandung Eceng Gondok (Eichornia Crassipes)terfermentasi. Agromedia, 32(1): 12-24.

Mangisah, I., Tristiarti, W. Murningsih, M.H. Nasoetion, E.S. Jayanti dan Y. Astuti. 2006. kecernaan nutrien Eceng Gondok yang Difermentasi dengan Aspergillus niger pada Ayam Broiler. J. Indon. Trop. Anim. Agric., 31(2):124-128.

Mangisah, I., B. Sukamto dan M. H. Nasution. 2009. Implementasi Daun Eceng Gondok Fermentasi dalam Ransum Itik. J. Indon. Trop. Anim. Agric., 34(2):127-132.

Mangisah, I., H.I. Wahyuni, Tristiarti, S. Surmarshi and S. Setyaningrum.2010.Nutritive value of fermented water hyacinth (Eichhornia crassipes) leaf with Aspergilus nigerin Tegal duck.J. Anim. Prod., 12(2): 100-104.
Rasyaf, M. 2002. Bahan Makanan Unggas di Indonesia. Cetakan Kesembilan. Kanisius.Yogyakarta.

Sumiyati dan A. Nurhaya.2003.Kecernaan Bahan kering, serat kasar, selulosa, dan hemiselulosa Kayambang (Salvina molesta) pada Itik Lokal (Salvina molesta Digestibility in Local Duck).J. Indon. Trop. Anim. Agric., Special Edition: 204-209.

Sohrah.2001. Pengaruh Penggunaan Eceng Gondok (Eichhornia crassipes) yang Difermentasikan dengan Thrichoderma Viridae Terhadap Kecernaan Protein, Energi dan Serat Kasar Ransum Broiler.Skripsi. Fakultas Peternakan Universitas Sam Ratulangi. Manado.

Steel, R. G. D. and J. H. Torrie, 1991.Prinsip dan Prosedur Statistika (Suatu Pendekatan Biometrik).PT. Gramedia Pustaka Utama. Jakarta.

Tanjung, M. 2001. Pengaruh Penggunaan Eceng Gondok (Eichhornia crassipes) yang Difermentasikan dengan Thrichoderma viridae Terhadap Efisiensi Penggunaan Makanan, Persentase Karkas, dan Persentase Lemak Abdomen Broiler.Skripsi.Fakultas Peternakan Universitas Sam Ratulangi. Manado

Tillman., A. D. H. Hartadi., S Reksohardiprojo., P. Soeharto dan L. Soekamto. 1989. Ilmu Makanan Ternak Dasar. Gajah Mada University Press. Yogyakarta. 